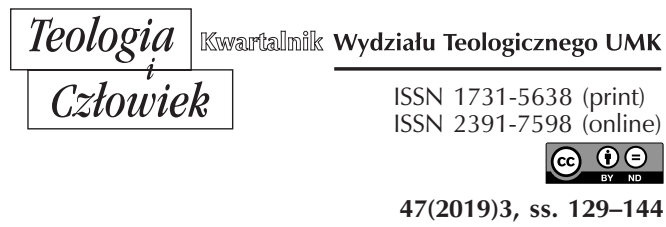

KS. MACIEJ FLADER*

UNIWERSYTET MIKOŁAJA KOPERNIKA W TORUNIU

FLADER.MACIEK@GMAIL.COM

ORCID 0000-0001-7671-7807

\title{
INKULTURACJA WIARY W „CYFROWY KONTYNENT”
}

DOI: http://dx.doi.org/10.12775/TiCz.2019.033

Streszczenie. Artykuł skupia się na ukazaniu roli inkulturacji w „cyfrowy kontynent”. Punktem wyjścia jest teologiczne pojęcie inkulturacji, pojmowane jako wszczepienie Ewangelii w inną kulturę, celem wyrażania prawdy Ewangelii w środkach wyrazu właściwych danej kulturze. Tak rozumiane pojęcie inkulturacji, zanalizowane pod kątem wymogów i dziedzin, zastosowano zgodnie ze wskazaniami papieża Benedykta XVI w rzeczywistość, którą wspomniany papież nazywał „cyfrowym kontynentem”. Efektem tego jest analiza dzieła inkulturacji i ewangelizacji wirtualnej rzeczywistości, a także postulaty z niej wynikającej.

Słowa kluczowe: inkulturacja; ewangelizacja; nowa ewangelizacja; cyfrowy kontynent; media społecznościowe.

Summary. The article focuses on showing the role of inculturation in the "digital continent". The starting point is the theological concept of inculturation understood as implanting the Gospel into a different culture in order to express the truth of the Gospel in the means of expression appropriate to a given culture. The concept of inculturation understood in this way, analyzed in terms of requirements and fields, was applied in ac-

* Doktorant na Wydziale Teologicznym Uniwersytetu Mikołaja Kopernika w Toruniu, absolwent dziennikarstwa w Wyższej Szkole Kultury Społecznej i Medialnej w Toruniu. 
cordance with the indications of Pope Benedict XVI in the reality that the aforementioned Pope called a "digital continent". The effect of this is the analysis of the work of inculturation and evangelization of virtual reality, as well as the postulates resulting from it.

Key words: inculturation; evangelization; new evangelization; digital continent; social media.

Odkąd Chrystus w paschalnym posłaniu nakazał uczniom, aby szli i głosili Ewangelię całemu stworzeniu, kultura Ewangelii konfrontowała się z kulturami ówczesnego świata. Szczególnie w czasach wielkich odkryć geograficznych misjonarze, głosząc Ewangelię, byli wezwani, aby przekazywać ją prostym językiem oraz by ukazywać jej bogactwo za pomocą znaków, które dla poszczególnych kręgów kulturowych były zrozumiałe i czytelne. Także współcześnie, w dobie mediów społecznościowych, wydaje się konieczne, aby przesłanie Ewangelii dostosowywać do wymogów obecnej kultury w taki jednak sposób, aby nie uszczuplać jej przesłania, ale raczej za pomocą dostępnych środków wyrazu ukazywać jej piękno i bogactwo.

W niniejszym artykule kluczowe wydaje się kilka pojęć - inkulturacji, ewangelizacji, cyfrowego kontynentu oraz pomocnicze, kultury. W kontekście i w obrębie tych pojęć krystalizuje się zjawisko inkulturacji wiary w „cyfrowy kontynent”.

Pojęcie inkulturacji jest niezwykle szerokie, zazwyczaj jednak definiuje dynamiczne związki religii i określonej kultury. Sam termin pochodzi $\mathrm{z}$ angielskiego inculturation. Po raz pierwszy termin ten został użyty w dziedzinie socjologii w roku 1948 przez Melville Johna Herskovitsa i rozumiano przez niego proces wrastania jednostki w kulturę otaczającego ją społeczeństwa. Na gruncie misjologii tego pojęcia używał Piotr Chalres na określenie związków Ewangelii z kulturą. W sensie teologicznym termin ten zaistniał w 1959 roku, podczas Tygodnia Misjologicznego na Uniwersytecie w Louvain w Belgii, nie precyzując jednak swego znaczenia. Dopiero John Masson w roku 1962, postulując potrzebę otwarcia Kościoła na wszelkie kultury poza krajami misyjnymi, stał się ojcem tego pojęcia ${ }^{1}$.

${ }^{1}$ D. Brzeziński, Wiara i jej celebracje w kulturze. Systematyzacja pojęć, „Teologia i Człowiek" 27 (2014) nr 3, s. 12. 
Teologiczne znaczenie pojęcia inkulturacji ma kilka warstw znaczeniowych, których podstawą jest absolutny charakter chrześcijaństwa i głoszenie imienia Boga. Po pierwsze, zakłada on potrzebę dialogu z kulturami ewangelizowanych narodów. Najlepszym przykładem jest wejście chrześcijaństwa pierwszych wieków w dialog z kulturą hellenistyczną, co zaowocowało - w dużym uproszczeniu - filozofią i teologią tomistyczną. Z drugiej strony, na co wskazują dokumenty Soboru Watykańskiego II, inkulturacja zakłada akomodację i adaptację Ewangelii do rodzimych kultur².

Modelem rozumienia inkulturacji jest wcielenie Syna Bożego, który upodobnił się do człowieka we wszystkim oprócz grzechu, a głosząc Dobrą Nowinę ludziom wszelkich kultur i ukazując swoistość nowego orędzia równocześnie przestrzegał żydowskich zwyczajów i obrzędów, posługiwał się kategoriami i symboliką judaizmu oraz uwzględniał mentalność określonej formacji kulturowej i społeczno-gospodarczej ${ }^{3}$.

Pierwszym papieżem, który użył pojęcia inkulturacji, był św. Jan Paweł II, który w adhortacji apostolskiej Catechesi tradendae wyjaśniał, że jest to słowo nowe, które jednak wyraża rzeczywistość Tajemnicy Wcielenia.

Katecheza, jak i ewangelizacja w ogóle, ma za zadanie wszczepienie siły Ewangelii w samą istotę jej kultury i ich zasadnicze elementy; dostrzegać to, co je jaśniej wyraża; szanować ich wartości i bogactwa. W ten sposób będzie mogła doprowadzić ludzi o różnych formach kultury do poznania ukrytej tajemnicy i dopomóc im w wydobywaniu $\mathrm{z}$ ich własnej żywej tradycji oryginalnych znaczeń chrześcijańskiego życia, sprawowania liturgii i sposobu myślenia ${ }^{4}$.

W tym miejscu papież zwrócił uwagę także na fakt, że Ewangelia nie może być oderwana od kultury. Głoszenie Dobrej Nowiny powinno odbywać się w dialogu apostolskim, który ma charakter dialogu kulturowego. Druga uwaga dotyczyła stwierdzenia, że Ewangelia swoją mocą przemienia kultury, przekształca i odradza, choć sama pozostaje bez zmiany. kol. 235.

2 J. Górski, S. Janeczek, Inkulturacja, w: Encyklopedia katolicka, t. 7, Lublin 1997,

3 Tamże, kol. 236.

4 Jan Paweł II, Catechesi tradendae, Wrocławska Księgarnia Archidiecezjalna, Wrocław 2017, nr 53. 
Ważna w kontekście inkulturacji jest również encyklika Redemptoris Missio. Tam św. Jan Paweł II określa inkulturację jako

wewnętrzne przekształcenie autentycznych wartości kulturowych przez ich integrację $\mathrm{w}$ chrześcijaństwie i zakorzenienie chrześcijaństwa w różnych kulturach. Jest to zatem proces głęboki i całościowy, który dotyczy zarówno orędzia chrześcijańskiego, jak też refleksji i konkretnej działalności Kościoła. Jest to również proces trudny, ponieważ nie może w żadnej mierze naruszyć specyfiki i integralności wiary chrześcijańskiej ${ }^{5}$.

W dalszych zaleceniach papież wskazywał, aby misjonarze uczyli się języka regionów, gdzie głoszą Dobrą Nowinę, odkrywali wartości kultury w bezpośrednim doświadczeniu i raz jeszcze podkreślił konieczność zgodności z Ewangelią i jedności z Kościołem powszechnym w procesie inkulturacji wiary ${ }^{6}$.

W kolejnych dokumentach papieskich, gdy była mowa o inkulturacji, powtarzały się zasady zgodności Ewangelii i jedności Kościoła Powszechnego, z drugiej znów strony zwracano uwagę na ubogacanie Kościoła innymi kulturami oraz na konieczność wypracowywania teologii, liturgii i struktur Kościoła, formacji biblijnej i formacji ewangelizatorów.

Również w dokumentach Kurii Rzymskiej zauważamy pojęcie inkulturacji. „Instrukcja o chrześcijańskiej wolności i wyzwoleniu”, wydana przez Kongregację Nauki Wiary, mówi o inkulturacji w następujący sposób:

Kościół Jako wspólnota łącząca różnorodność i jedność, dzięki swej obecności w całym świecie, przyjmuje z każdej kultury to, co w niej znajduje pozytywnego. Inkulturacja nie jest jednakże zwyczajną zewnętrzną akceptacją; jest ona wewnętrznym przekształceniem autentycznych wartości kulturowych, poprzez ich włączenie w chrześcijaństwo; jest zakorzenieniem się chrześcijaństwa w różnych kulturach ludzkich. Rozdział między Ewangelią i kulturą jest dramatem, którego wspomniane

${ }_{5}^{5}$ Tenże, Redemptoris missio, w: Encykliki Ojca Świętego Jana Pawła II, t. 1, Wydawnictwo św. Stanisława B.M., Kraków 1996, nr 52.

${ }^{6}$ S. Górzna, Inkulturacja $w$ nauczaniu papieża Jana Pawła II $i w$ dokumentach Kurii Rzymskiej, „Studia Elbląskie” XVIII (2017), s. 530. 
problemy są smutną ilustracją. Potrzebny jest więc wielkoduszny wysiłek ewangelizacji kultur ${ }^{7}$.

Z kolei Międzynarodowa Komisja Teologiczna, w dokumencie pt. „Wiara i Inkulturacja”, definiuje inkulturację jako

wprowadzenie orędzia Chrystusa w określone środowisko społeczno-kulturowe, wzywając do wiary według wszystkich jej własnych wartości, uwzględniwszy, że są one do pogodzenia z Ewangelią. Pojęcie inkulturacji uwzględnia ideę wzrostu, wzajemnego ubogacenia osób i grup na mocy spotkania Ewangelii ze środowiskiem społecznym ${ }^{8}$.

Wyróżnia się trzy typy inkulturacji odnośnie do celebracji wiary. Akomodacja odnosi się szczególnie do liturgii i polega na doborze elementów liturgii do sytuacji egzystencjalnej uczestników, drugi typ to akulturacja, która polega na modyfikacjach w środkach wyrazu wiary, opartych na kulturze danego narodu. To zmiany strukturalne i formalne; Trzeci typ to inkulturacja $\mathrm{w}$ sensie ścisłym, która polega na reinterpretacji i nadaniu nowego znaczenia, jeżeli to możliwe, elementów kultury. W jej wyniku powstaje nowa forma chrześcijańska opierająca się na miejscowym dziedzictwie kulturowym ${ }^{9}$.

Inkulturacja zawsze przebiega $w$ trzech etapach. Pierwszy etap to kontakt z kulturą, drugi etap to asymilacja, która oznacza umiejscowienie Ewangelii w centrum danej kultury. Wtedy to dochodzi do konfrontacji wartości ewangelicznych $\mathrm{z}$ fundamentalnymi wartościami ewangelizowanej kultury. Wówczas konieczne jest oczyszczenie ewangelizowanej kultury z tych elementów, które są sprzeczne z Ewangelią. Trzeci etap to wyrażanie doświadczania wiary $\mathrm{w}$ nowych, zgodnych $\mathrm{z}$ danymi tradycjami, formach kulturowych ${ }^{10}$.

7 Kongregacja Nauki Wiary, Instrukcja o chrześcijańskiej wolności i wyzwoleniu, OsRomPol 1986, nr 2, s. 15.

${ }^{8}$ Międzynarodowa Komisja Teologiczna, Wiara i inkulturacja, w: Od wiary do teologii. Dokumenty Międzynarodowej Komisji Teologicznej 1969-1996, red. J. Królikowski, Kraków 2000, s. 256.

9 D. Brzeziński, Wiara i jej celebracje w kulturze. Systematyzacja pojęć, „Teologia i Człowiek" 27 (2014) nr 3, s. 17-18.

${ }^{10}$ R. Jaszczuk, Ewangelizacja kultur $i$ inkulturacja Ewangelii, Missio Polonia, Warszawa 2012, s. 73-75. 
W charakteryzowaniu procesu inkulturacji zwraca się uwagę na ideę wzrostu, dojrzewania, wzajemnego wzbogacenia się osób i całych grup w związku ze spotkaniem się Ewangelii i miejscowego środowiska społecznego. W związku z tym, wyróżnia się elementy, dziedziny i wymogi inkulturacji. W niniejszej analizy, zwrócimy uwagę szczególnie na elementy, możliwe do zastosowania na przestrzeni cyfrowej kultury.

Jednym $\mathrm{z}$ wymogów inkulturacji jest objęcie swoim zasięgiem większości osób będących w danej kulturze. Zatem inkulturacja nie może ograniczyć się do jednostek pozostających na uboczu życia społecznego i kulturalnego. Taka ewangelizacja powinna dążyć do nawrócenia całej społeczności i przeobrażenia od wewnątrz jej kultury. Wymóg dotyczący formacji kapłanów rodzimych, zakonników i zaangażowanych świeckich ma realizować się w przepowiadaniu, mającym więcej cech kerygmatycznych aniżeli informacyjnych. W tym kontekście mówi się także o rodzimych świętych, jako owocach życia Ewangelią. Wśród ważnych wymogów inkulturacji stawia się również stworzenie samodzielnych struktur Kościoła, jednak w naszym kontekście te wymogi nie będą brane pod uwagę, ze względu na aprzestrzenny charakter Internetu. Szczególnie natomiast ważne wydają się wymogi dotyczące realizowania nauczycielskiego zadania Kościoła. Wymaga to dostosowania języka do miejscowych standardów, prowadzenia katechezy, regularnej odnowy oraz poszukiwań teologiczno-pastoralnych ${ }^{11}$.

Podsumowując dotychczasowe rozważania dotyczące inkulturacji, należy stwierdzić, że jest to pojęcie, które do Kościoła katolickiego weszło stosunkowo późno, bo po Soborze Watykańskim II, natomiast definiuje ono rzeczywistość, która w Kościele była obecna już kilku wieków w związku z działalnością misyjną. Dwa główne aspekty inkulturacji to przemiana kultur w duchu Ewangelii, ale także zachowanie tych elementów innych kultur, które nie sprzeciwiają się Ewangelii. Podstawowe zasady inkulturacji to wierność Ewangelii i jedność Kościoła. Inkulturacja realizuje się na określonych przestrzeniach i dziedzinach życia społecznego i dokonuje się jako proces wzrostu, którego efektem jest kultura ubogacona światłem Ewangelii.

11 J. Różański, Główne dziedziny inkulturacji, „Studia Theologica Varsoviensia” 49 (2011) nr 2, s. 44-61. 
Warto teraz przeanalizować pojęcie ewangelizacji oraz nowej ewangelizacji tak, by uzupełnić pojęcie inkulturacji. Termin ten pochodzi od greckiego słowa ewangelia, które oznacza radosne przesłanie albo nagrodę, którą otrzymywał ten, kto ją przynosił. Stąd ewangelizować znaczy głosić Dobrą Nowinę, a w Nowym Testamencie oznacza także ogłaszanie nadejścia czasów mesjańskich, powszechne i ostateczne królowanie Boga. Rozumienie terminu ewangelizacja doprecyzowano w 1974 roku podczas Synodu Biskupów. Według ojców synodalnych ewangelizacja to wszelka działalność Kościoła zgodna z Bożym planem, po drugie spełnianie misji prorockiej, kapłańskiej i wykonywanie władzy, po trzecie kerygmat i po czwarte głoszenie i wyjaśnianie Ewangelii niechrześcijanom oraz pielęgnowanie jej wśród chrześcijan ${ }^{12}$.

W tym kontekście nowa ewangelizacja będzie głoszeniem i wyjaśnianiem Ewangelii, kerygmatu, głownie chrześcijanom, którzy zagubili swoją wiarę. W myśl tego, co mówił św. Jan Paweł II: jest ona „nowa w swym zapale, w swych metodach, w swym wyrazie"13. To znaczy, że nowa ewangelizacja jest głoszeniem Ewangelii - tej samej od początku Kościoła - w nowych formach wyrazu, w nowym sposobie i zapale oraz nowymi metodami. Efektem nowej ewangelizacji powinno być doprowadzenie osoby do osobistego spotkania z Chrystusem i do wyboru Go jako jedynego Zbawiciela i Pana.

Podsumowując tę część rozważań, należy zadać pytanie o różnicę między terminem inkulturacji Ewangelii i ewangelizacji kultur. Jak wyjaśnia Radosław Jaszczuk - ewangelizacja kultur podkreśla akcję, która nie utożsamia się z żadną kulturą i której celem jest inkulturacja, natomiast inkulturacja podkreśla konieczność zaistnienia procesu, w którym ewangelizacja powinna być inkarnacją Ewangelii w kultury, biorąc pod uwage jej wartości ${ }^{14}$.

12 J. Nowicka, Rola inkulturacji w nowej ewangelizacji, „Annales Missiologici Posnanienses" 22 (2017), s. 84.

13 Jan Paweł II, Przemówienie do Rady Konferencji Episkopatów Ameryki Łacińskiej, (Port-au-Prince 9 III.1983), OsRomPol 4 (1983), s. 29.

${ }^{14}$ R. Jaszczuk, Ewangelizacja kultur, s. 71-72. 


\section{CYFROWY KONTYNENT}

Papieże minionych lat często podejmowali zagadnienie Internetu oraz mediów społecznościowych, zazwyczaj w kontekście ewangelizacji. Jako pierwszy uczynił to św. Jan Paweł II, który już w 1990 roku w orędziu na Światowy Dzień Środków Społecznego Przekazu mówił o misji Kościoła w erze komputerów ${ }^{15}$. Kilkanaście lat później, w 2002 roku, Jan Paweł II ukazał wielkie możliwości tkwiące w Internecie, jako nowym medium głoszenia Ewangelii. Mówił o realizmie i zaufaniu, z jakim Kościół podchodzi do Internetu, a zarazem o konieczności dobrego wykorzystania tego środka komunikacji. Według Papieża, może on stać się okazją do pierwszego spotkania z chrześcijańskim przesłaniem, szczególnie dla młodych - a zatem narzędziem pierwszej ewangelizacji. Może także być środkiem utrwalania, nauczania i katechezy, może także pomóc w przygotowaniu na spotkanie z Chrystusem ${ }^{16}$.

Jednak dopiero Benedykt XVI, jako pierwszy papież, mówił o mediach społecznościowych czy sieciach społecznościowych - tak w swoich dokumentach określa portale społecznościowe. On wprowadził pojęcie „cyfrowy kontynent” w Orędziu na 43. Światowy Dzień Środków Społecznego Przekazu w kontekście ewangelizacji nowej rodzącej się kultury ${ }^{17}$. Warto zatem krótko scharakteryzować „cyfrowy kontynent” jako płaszczyznę inkulturacji i ewangelizacji. Papież Franciszek sprecyzował pojęcie „cyfrowego kontynentu” w słowach: „Wielki kontynent cyfrowy nie jest po prostu technologią, ale tworzą go realni ludzie oraz to, co mają w swoim wnętrzu: własne nadzieje, własne cierpienia, własne lęki, poszukiwanie prawdy, piękna i dobra” ${ }^{18}$. „Cyfrowy kontynent” to rzeczywistość

15 Jan Paweł II, Misja Kościoła w erze komputerów, Orędzie na 24. Światowy Dzień Środków Społecznego Przekazu (24 I 1990), w: Internet i Kościót, red. J. Kloch, Warszawa 2011, s. 18-20.

${ }^{16}$ Tenże, Internet: nowe forum głoszenia Ewangelii, Orędzie na 36. Światowy Dzień Środków Społecznego Przekazu (24 I 2002), w: Internet i Kościół, s. 24-26.

${ }_{17}$ Benedykt XVI, Nowe technologie, nowe relacje. Trzeba rozpowszechniać kulture szacunku, dialogu i przyjaźni (24 I 2009), w: Internet i Kościół, s. 75.

18 Przemówienie Ojca Świętego Franciszka - audiencja dla uczestników Zgromadzenia Plenarnego Papieskiej Rady ds. Środków Społecznego Przekazu, http://w2.vatican. $\mathrm{va} /$ content/francesco/pl/speeches/2013/september/documents/papa-francesco_20130921_ plenaria-pccs.html [data dostępu: 10.04.2018r.]. 
tworzona prze ludzkie społeczności, gromadzące się w przestrzeni cyfrowej. Podstawą ich gromadzenia są media społecznościowe, definiowane jako funkcjonalne technologie, wykorzystywane przez użytkowników do dzielenia się opiniami, poglądami czy doświadczeniami ${ }^{19}$. Z kolei nieco głębsza definicja widzi media społecznościowe jako „grupę aplikacji internetowych bazujących na ideologicznych i technologicznych założeniach Web 2.0 oraz umożliwiająca tworzenie i wymianę treści generowanych przez użytkownika"20. Jeszcze bardziej ścisłe pojęcie, odnoszące się już tylko do portali społecznościowych, definiuje je jako internetową usługę umożliwiającą: tworzenie publicznych lub częściowo publicznych profilów, kształtowanie listy innych użytkowników, z którymi utrzymuję się kontakty, przegląda listy użytkowników, którzy są w systemie ${ }^{21}$.

Z powyższych definicji wynika, że dzisiejsze portale społecznościowe są platformami wymiany ludzkich myśli, poglądów i upodobań. Zakładają one oczywiście komunikację, ale realizowaną w nowym modelu. Jak wskazuje papież Benedykt XVI:

W świecie cyfrowym przekazywanie informacji oznacza coraz częściej udostępnianie ich w sieci społecznościowej, gdzie osoby wymieniają je między sobą. Jasny podział na producentów informacji i ich konsumentów zostaje relatywizowany, natomiast przekaz dąży do tego, by być nie tylko wymianą danych, ale w coraz większej mierze także formą ich udostępniania ${ }^{22}$.

Jak zauważa Paul Levinson, w mediach społecznościowych pojawiają się nowe formy komunikacyjne. Pismo odgrywa wciąż istotną rolę we wszystkich mediach społecznościowych, nawet jeśli pojawia się wyłączenie jako podpis czy tytuł pod zdjęciem lub filmem. Dominują

19 D. Kaznowski, Nowy marketing $w$ Internecie, VFP Communications Ltd., Warszawa 2007, s. 63.

20 A. M. Kaplan, M. Haenlein, Users of the world, unite! The challenges and opportunities of Social Media, "Business Horizons" 53 (2010), s. 61.

${ }^{21}$ D. Boyd, N. Ellison, Social Network Sites: Definition, History, And Scholarship, "Journal of Computer-Mediated Communication" 13 (2008), s. 211.

${ }^{22}$ Benedykt XVI, Nowe technologie komunikacyjne i głoszenie Ewangelii, Orędzie na 45. Światowy Dzień Środków Społecznego Przekazu (24 I 2011), w: Internet i Kościół, s. 89-93. 
jednak dźwięk, audiowizualność i fotografia. Inną charakterystyczną cechą komunikacji jest informowanie i jak twierdzi wspomniany autor: „informacja jest celem, a nie formą przekazu”23. W końcu, komunikacja odbywa się wewnątrz określonych, społecznych grup, które pełnią funkcję społeczeństwa.

Najbardziej obszerną charakterystykę komunikację w mediach społecznościowych daje Robert K. Logan, który, wychodząc od początkowych pięciu cech komunikacji w Internecie, rozwija je w czternastu charakteryzujących komunikację w mediach społecznościowych. Robert K. Logan formułuje tożsamość Internetu poprzez pięć cech: dwukierunkową komunikację, łatwość dostępu i rozpowszechniania informacji, ciągłość uczenia się, równość i integrację oraz społeczność ${ }^{24}$. Ukazują one również bardzo dobrze zjawisko komunikacji w mediach społecznościowych. Trzeba dodać, że powyższe cechy oddawały także rzeczywistość mass mediów, stąd Internet jawi się jako pośredni, choć zdecydowanie inny w procesie komunikacji, pomiędzy tradycyjnymi mediami a tzw. nowymi mediami, do których zaliczamy także media społecznościowe.

Przemiany w świecie mediów wprowadzają, zdaniem Papieża, także całą gamę postaw: niepokój, sprzeczność, kreatywność, entuzjazm i ciekawość. Z jednej strony media te budują solidarności i wspólnotę, zacieśniają relacje międzyludzkie, ale wymagają także bycia autentycznym i wiernym samemu sobie. Dynamika nowych mediów angażuje człowieka jeszcze bardziej w przekaz ${ }^{25}$.

Zatem „cyfrowy kontynent” to wirtualny świat Internetu, mediów społecznościowych, szczególnie zaś portali, które są platformą cyfrowych spotkań, wymiany poglądów, treści, upodobań - słowem świat, w którym dzisiaj większość populacji spędza kilka godzin dziennie, a często jest to dla nich alternatywna rzeczywistość lub świat, do którego uciekają, nie radząc sobie z ciężarem świata realnego. Precyzując to określenie, są to wszystkie profile na mediach społecznościowych, blogi, vlogi i inne treści

23 P. Levinson, Nowe Nowe media, WAM, Kraków 2010, s. 17.

${ }^{24}$ R. K. Logan, Understanding New Media: Extending Marshall Mcluhan, Peter Lang 2010, s. 48.

${ }^{25}$ W. Mleczko, Jak ewangelizować świat cyfrowy? Wskazania Benedykta XVI w orędziach na Światowe Dni Środków Społecznego Przekazu, „Studia Socialia Cracoviensia" 6 (2014) nr 1(10), s. 203. 
istniejące $\mathrm{w}$ przestrzeni Internetu. Znamienne dla przemówień papieży jest to, że pierwsze ujmowały „cyfrowy kontynent” jako narzędzie, z czasem jednak zaczęto spoglądać nań jako na przestrzeń, w której konieczna jest obecność Dobrej Nowiny oraz ewangelizacyjne dzieło Kościoła poprzez świadectwo życia cyfrowych ewangelizatorów. Stąd wydaje się teraz konieczne, aby zarysować choćby niektóre dziedziny możliwej inkulturacji wiary w przestrzeń „cyfrowego kontynentu”. Jakkolwiek specyfika cyfrowego, a zatem wirtualnego kontynentu, domaga się dostosowania samego pojęcia inkulturacji, to sam ciężar znaczeniowy wspomnianego pojęcia pozostaje bez zmian.

\section{INKULTURACJA W „CYFROWYM KONTYNENCIE”}

Na początku należy wspomnieć o tym, że papież Benedykt XVI w swoich orędziach wspomina dosłownie o inkulturacji, a zatem jest uzasadnione używanie tego terminu dla zaszczepienie Dobrej Nowiny w nowej kulturze komunikacyjnej. Nawiązując do inkulturacji w czasach Kościoła pierwotnego, papież zaznacza, że najpierw konieczne jest dogłębne poznanie nowej kultury. Jest to warunek jakiejkolwiek obecności w tej przestrzeni. Kolejnym warunkiem jest posługiwanie się nowym językiem używanym i zrozumiałym w dzisiejszej kulturze komunikacyjnej ${ }^{26}$. Jest to konieczne, by Ewangelia zabrzmiała w całym swoim bogactwie. Papież wspomina także, że zazwyczaj przesłaniu w „cyfrowym kontynencie” towarzyszy dźwięk i obraz, wskazując konkretnie, że to są te formy wyrazu, w których Ewangelia powinna być dzisiaj wyrażana ${ }^{27}$.

Powyższe rozważania na temat inkulturacji wskazały dziedziny życia społecznego, w których spełnienie pewnych wymogów daje gwarancję, że inkulturacja jako proces przebiega pomyślnie. Pierwszym z nich jest konieczność, by objęła ona swoim zasięgiem całą społeczność zamieszkiwanego kontynentu. O ile media cyfrowe dają taką możliwość, o tyle należy zwrócić na fakt blokowania stron chrześcijańskich i katolickich,

26 Tamże, s. 205.

27 Benedykt XVI, Sieci społecznościowe: Port prawdy $i$ wiary, nowe miejsca ewangelizacji, Orędzie na 47. Światowy Dzień Środków Społecznego Przekazu (24 I 2013), OsRomPol 3-4 (2013), s. 10-12. 
a także blokowania profili działaczy pro-life na Facebooku. Przeszkodą mogą być algorytmy nowych mediów, które zamykają przekaz Ewangelii w obrębie właściwie zamkniętych środowisk. Dobrym sposobem ewangelizacji jest tutaj świadectwo ludzi sławnych, którzy na swoich profilach oficjalni mówią o swoich przekonaniach i o tym, że są ludźmi wierzącymi ${ }^{28}$.

Kolejnym wymogiem inkulturacji jest wymóg rodzimych kapłanów i osób konsekrowanych. W tej przestrzeni działa wielu księży i zakonników, którzy poprzez głoszenie Dobrej Nowiny, blogowani i vlogowanie, a także organizowanie tzw. rekolekcji internetowych, zaznaczają swoją obecność na cyfrowym kontynencie ${ }^{29}$.

Najlepiej rozwiniętym elementem i zarazem wymogiem inkulturacji jest obecność ludzi świeckich i ich zaangażowanie $\mathrm{w}$ dziedzinie ewangelizacji i życia apostolskiego. Każdy wpis oraz treść umieszczona na prywatnym profilu, mająca charakter głoszenia Ewangelii, staje się zaangażowaniem. Zatem świadectwo wiary, modlitwa, grafika nawiązująca do wiary w Boga, jest w pewnym sensie działalnością apostolską ${ }^{30}$. W sensie ścisłym zaś, do takiej aktywności możemy zaliczyć oficjalne profile ludzi, którzy prowadzą blogi, vlogi o charakterze katolickim. Przykładem może być choćby strona i kanał na portalu YouTube należący do Joli Szymańskiej - hipster-katoliczki, której celem jest głoszenie Ewangelii w codziennym życiu.

Ważnym z punktu widzenia inkulturacji jest także obecność $\mathrm{w}$ „cyfrowym kontynencie" stron mających charakter oficjalnych profili struktur kościelnych. Takie profile posiada zarówno Stolica Apostolska ${ }^{31}$, jak i Kon-

${ }^{28}$ Ewa Chodakowska publicznie przyznała się do wiary. Pojawiły się groźby i szantaż, https://www.deon.pl/inteligentne-zycie/lifestyle/art,626,ewa-chodakowskapublicznie-przyznala-sie-do-wiary-pojawily-sie-grozby-i-szantaz.html, [data dostępu: 10.04.2018].

${ }_{29}$ M. Przybysz, Kapłan w sieci uwikłany. Dylematy obecności księdza w mediach, w: Media $w$ transformacji, red. A. Gralczyk, K. Marcyński, M. Przybysz, Dom wydawniczy Elipsa, Warszawa 2013, s. 105-122.

${ }^{30}$ B. Bilicka, Chrześcijański styl obecności na „cyfrowym kontynencie” w orędziach Benedykta XVI, „Forum Teologiczne” 16 (2015), s. 149.

${ }^{31}$ https://www.facebook.com/Vatican-News-Polski-569117036792046/ [data dostępu: 10.04.2018]. 
ferencja Episkopatu Polski ${ }^{32}$, a także większość diecezji i dużo mniejsza część parafii. Natomiast na Twitterze, obok oficjalnego konta Ojca Świętego w kilku językach, jest wiele kont należących do osób duchownych, w tym do biskupów.

Kolejnym znakiem inkulturacji jest obecność na portalach społecznościowych profili oraz stron internetowych transmitujących na żywo celebracje liturgiczne, Msze Święte oraz inne nabożeństwa lub rozważania Słowa Bożego. Jakkolwiek z punktu widzenia Kościoła Katolickiego dla działania sakramentów konieczna jest realna obecność, to z pewnością $\mathrm{z}$ jednej strony jest to dowód pewnego etapu zakorzenienia się kultury chrześcijańskiej w kulturze nowych mediów, a z drugiej strony są one pożyteczne i budujące duchowość ludzi, szczególnie, gdy środki te wykorzystywane są jako dodatkowe i pomocnicze w porównaniu do tych liturgicznych celebracji, które odbywają się na co dzień w parafialnych kościołach, w szczególności zaś niedzielnej Eucharystii.

Innym aspektem inkulturacji jest, nazwana przez Benedykta XVI, „diakonia kultury”. Realizuje się ona poprzez krzewienie kultury poszanowania godności i wartości osoby ludzkiej, dialogu opartego na szczerym poszukiwaniu prawdy i przyjaźni zdolnej do rozwijania talentów każdego człowieka ${ }^{33}$.

Kolejnym wymogiem owocnej obecności wierzących w przestrzeni wirtualnej jest autentyczność, dawanie świadectwa prawdzie, a w tym kontekście opieranie się pokusie popularności kosztem rozcieńczania prawdy. Na tej płaszczyźnie człowiek dzieli się nie tylko swoimi poglądami i przekonaniami, ale niejako dzieli się tym, kim jest. Autentyczność ludzi wierzących staje się widoczna dzięki dzieleniu się głębokim źródłem ich nadziei i radości: wiarą w Boga bogatego w miłosierdzie i miłość objawioną w Chrystusie Jezusie. Zatem autentyczność życia chrześcijańskiego będzie stylem obecności w świecie cyfrowym ${ }^{34}$.

W 2012 roku w kolejnym orędziu Benedykt XVI mówił o milczeniu w świecie cyfrowym. Mówił o tym, że w szumie medialnym, w prze-

32 https://www.facebook.com/episkopatpolski/ [data dostępu: 10.04.2018].

${ }^{33}$ Benedykt XVI, Nowe technologie, nowe relacje. Trzeba rozpowszechniać kulturę szacunku, dialogu i przyjaźni (24 I 2009), s. 75.

${ }^{34}$ Benedykt XVI, Nowe technologie komunikacyjne i głoszenie Ewangelii, Orędzie na 45. Światowy Dzień Środków Społecznego Przekazu (24 I 2011), s. 90. 
strzeni, gdzie człowiek bombardowany jest ogromną ilością informacji, dźwięków i obrazów, łatwo może się zatracić. Stąd Papież podjął temat relacji między milczeniem a słowem. Kiedy słowo i milczenie nawzajem się wykluczają, proces komunikacji ulega pogorszeniu. „Tam, gdzie jest dużo komunikatów i informacji, milczenie staje się niezbędne, by rozróżnić to, co ważne od tego, co zbędne lub marginalne"35.

Zdaniem Papieża to te przestrzenie pomagają przemyśleć, skłonić do refleksji oraz pozostać sam na sam z orędziem Ewangelii, dać mówić Bogu do serca, zgłębić w sobie Jego orędzie i otworzyć się na odpowiedź do Niego. Zdolność milczenia, jest tą zdolnością, która pomaga odróżnić ewangelizatora autentycznego i zakorzenionego w Chrystusie, od tego, który jest tylko jego karykaturą.

Słowo i milczenie. Nauczyć się komunikowania znaczy zdobyć umiejętność słuchania, kontemplacji, a nie tylko mówienia. Jest to szczególnie ważne dla tych, którzy pracują na polu ewangelizacji: zarówno milczenie, jak i słowo są istotnymi i nieodłącznymi elementami działań podejmowanych przez Kościół w dziedzinie środków przekazu, by na nowo głosić Chrystusa we współczesnym świecie ${ }^{36}$.

Wymowne wydaje się zakończenie orędzia z roku 2011, w którym Benedykt XVI wskazuje na konieczność bezpośredniej relacji. Jakkolwiek głoszenie Ewangelii może dokonywać się w przestrzeni „cyfrowego kontynentu”, istnie wiele serwisów umożliwiających modlitwę, skupienie, rozważanie Bożego słowa, to jednak nic nigdy nie zastąpi bezpośrednio kontaktu i bezpośredniej relacji. Jest to szczególnie ważne w perspektywie zagrożenia izolowaniem się, zrywaniem realnych więzi społecznych, uciekaniem do alternatywnego świata, które wciąż pozostają pokusą, dla wszystkich, dla których ekran monitora lub smartfon pozostaje buforem bezpieczeństwa i wygody wobec wyzwania budowanie relacji z Bogiem i człowiekiem ${ }^{37}$.

35 Benedykt XVI, Milczenie i słowo droga ewangelizacji, Orędzie na 46. Światowy Dzień Środków Społecznego Przekazu (24 I 2012), https://w2.vatican.va/content/benedict-

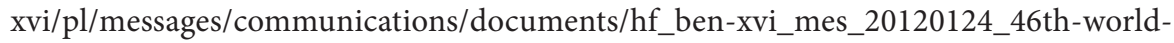
communications-day.html [data dostępu: 10.04.2018].

36 Tamże.

37 Benedykt XVI, Nowe technologie komunikacyjne i głoszenie Ewangelii, Orędzie na 45. Światowy Dzień Środków Społecznego Przekazu (24 I 2011), s. 93. 
Reasumując, temat inkulturacji wiary w „cyfrowy kontynent” jest bardzo obszernym zagadnieniem, który może być podejmowany pod różnym kątem. Jednakże ten artykuł miał za zadanie nakreślić temat w oparciu o nauczanie Kościoła oraz wskazać przestrzenie, w których inkulturacja wiary $\mathrm{w}$ „cyfrowy kontynent” może przebiegać z pożytkiem nie tylko dla wspólnoty Kościoła, ale także dla samych użytkowników wirtualnego świata. Stąd szczególnie obecność świadków wiary oraz kapłanów i osób konsekrowanych, a także działalność ewangelizacyjna w obrębie cyfrowego kontynentu, jawią się jako najbardziej skuteczne i cieszące się już teraz popularnością środki, w których Kościół może się realizować, a Ewangelia wybrzmiewać w języku nowych mediów.

\section{BIBLIOGRAFIA}

Benedykt XVI, Milczenie i stowo droga ewangelizacji, Orędzie na 46. Światowy Dzień Środków Społecznego Przekazu (24 I 2012), https://w2.vatican.va/content/benedict-xvi/pl/messages/communications/documents/hf_ben-xvi_mes_20120124_46th-world-communications-day.html [data dostęp: 10.04.2018].

Benedykt XVI, Sieci społecznościowe: Port prawdy i wiary, nowe miejsca ewangelizacji, Orędzie na 47. Światowy Dzień Środków Społecznego Przekazu (24 I 2013), OsRomPol 3-4 (2013), s. 10-12.

Benedykt XVI, Nowe technologie komunikacyjne i głoszenie Ewangelii, Orędzie na 45. Światowy Dzień Środków Społecznego Przekazu $(24$ I 2011), w: Internet i Kościót, s. 89-93.

Benedykt XVI, Nowe technologie, nowe relacje. Trzeba rozpowszechniać kulturę szacunku, dialogu i przyjaźni(24 I 2009), w: Internet i Kościół, s. 71-75.

Bilicka B., Chrześcijański styk obecności na „cyfrowym kontynencie” w orędziach Benedykta XVI, „Forum Teologiczne” 16 (2015), s. 139-151.

Boyd D., Ellison N., Social Network Sites: Definition, History, And Scholarship, "Journal of Computer-Mediated Communication" 13 (2008), s. 210-230.

Brzeziński D., Wiara i jej celebracje w kulturze. Systematyzacja pojęć, „Teologia i Człowiek” 27 (2014) nr 3, s. 12. (w bibliografii: $11-20$ )

Ewa Chodakowska publicznie przyznała się do wiary. Pojawily się groźby i szantaż, https:// www.deon.pl/inteligentne-zycie/lifestyle/art,626,ewa-chodakowska-publicznieprzyznala-sie-do-wiary-pojawily-sie-grozby-i-szantaz.html [data dostępu: 10.04.2018].

Górski J., Janeczek S., Inkulturacja, w: Encyklopedia katolicka, t. 7, Lublin 1997, kol. 235-237. 
Górzna S., Inkulturacja w nauczaniu papieża Jana Pawła II $i$ w dokumentach Kurii Rzymskiej, „Studia Elbląskie” XVIII (2017), s. 525-536.

Jan Paweł II, Catechesi tradendae, Wrocławska Księgarnia Archidiecezjalna, Wrocław 2017, nr 53.

Jan Paweł II, Internet: nowe forum głoszenia Ewangelii, Orędzie na 36. Światowy Dzień Środków Społecznego Przekazu (24 I 2002), w: Internet i Kościół, s. 23-27.

Jan Paweł II, Misja Kościoła w erze komputerów, Orędzie na 24. Światowy Dzień Środków Społecznego Przekazu (24 I 1990), w: Internet i Kościót, red. J. Kloch, Warszawa 2011, s. 17-21.

Jan Paweł II, Przemówienie do Rady Konferencji Episkopatów Ameryki Łacińskiej, (Port-au-Prince 9 III 1983), OsRomPol 4 (1983), s. 29-31.

Jan Paweł II, Redemptoris missio, w: Encykliki Ojca Świętego Jana Pawła II, t. 1, Wydawnictwo św. Stanisława B.M., Kraków 1996, nr 52. (w bibliografii 377-460).

Jaszczuk R., Ewangelizacja kultur $i$ inkulturacja Ewangelii, Missio Polonia, Warszawa 2012, s. 73-75.

Kaplan A. M, Haenlein M., Users of the world, unite! The challenges and opportunities of Social Media, "Business Horizons" 53 (2010), s. 59-68.

Kaznowski D., Nowy marketing $w$ Internecie, VFP Communications Ltd., Warszawa 2007, s. 63.

Kongregacja Nauki Wiary, Instrukcja o chrześcijańskiej wolności i wyzwoleniu, OsRomPol 1986, nr 2, s. 15.

Levinson P., Nowe Nowe media, WAM, Kraków 2010, s. 17.

Logan R. K., Understanding New Media: Extending Marshall Mcluhan, Peter Lang 2010. Międzynarodowa Komisja Teologiczna, Wiara i inkulturacja, w: Od wiary do teologii. Dokumenty Międzynarodowej Komisji Teologicznej 1969-1996, red. J. Królikowski, Kraków 2000, s. 251-271.

Mleczko W., Jak ewangelizować świat cyfrowy? Wskazania Benedykta XVI w orędziach na Światowe Dni Środków Społecznego Przekazu, „Studia Socialia Cracoviensia” 6 (2014) nr 1 (10), s. 197-208.

Nowicka J., Rola inkulturacji w nowej ewangelizacji, „Annales Missiologici Posnanienses” 22 (2017), s. 83-97.

Przemówienie Ojca Świętego Franciszka - audiencja dla uczestników Zgromadzenia Plenarnego Papieskiej Rady ds. Środków Społecznego Przekazu, http://w2.vatican.va/content/francesco/pl/speeches/2013/september/documents/papa-francesco_20130921_plenaria-pccs.html [dostęp dostęp: 10.04.2018].

Przybysz M., Kapłan w sieci uwikłany. Dylematy obecności księdza w mediach, w: Media $w$ transformacji, red. A. Gralczyk, K. Marcyński, M. Przybysz, Dom Wydawniczy Elipsa, Warszawa 2013, s. 105-122.

Różański J., Główne dziedziny inkulturacji, „Studia Theologica Varsoviensia” 49 (2011) nr 2, s. 44-78. 